\title{
Theoretical-practical acquisition of topics relevant to patient safety: dilemmas in the training of nurses ${ }^{a}$
}

\author{
Aquisição teórico-prática de tópicos relevantes à segurança do paciente: dilemas na formação de \\ enfermeiros
}

\section{Adquisición teórico-práctico de tópicos relevantes sobre seguridad del paciente: dilemas en la formación de enfermeros}

\begin{abstract}
Lucas Lazarini Bim¹
Felipe Lazarini Bim ${ }^{1}$

Andrea Mara Bernardes da Silva ${ }^{1}$

Alvaro Francisco Lopes de Sousa ${ }^{1}$

Paula Regina de Souza Hermann ${ }^{2}$

Denise de Andrade

Vanderlei José Hass
\end{abstract}

\begin{abstract}
1. Universidade de São Paulo,
Ribeirão Preto, SP, Brazil.

2. Universidade de Brasília, Faculdade

de Ceilândia, Brasília, DF, Brazil.

3. Universidade Federal do Triângulo Mineiro, Uberaba, MG, Brazil.
\end{abstract}

Corresponding author:

Denise de Andrade.

E-mail: dandrade@eerp.usp.br

Submitted on $05 / 05 / 2017$.

Accepted on 05/17/2017.

DOI: 10.1590/2177-9465-EAN-2017-0127

\begin{abstract}
Objective: To investigate content associated with patient safety included in the curricula of undergraduate nursing courses of two Brazilian higher educational institutions. Method: A descriptive survey study was carried out with 119 students of nursing courses (licentiate and bachelor degree), from August to September 2016. The topics investigated were based on the WHO patient safety curriculum guide: multi-professional edition. Armed with the data, univariate and bivariate analyses were carried out. Results: Of the 46 content areas investigated in the questionnaire, two scored high in non-achievement in theoretical or practical activities, namely "the culture of blame" and "community-acquired infection." Licentiate and bachelor degree students reported a higher acquisition in theoretical classes $(p=0.012)$, whereas bachelor degree students reported similar acquisition in theory and practice $(p=0.013)$. Conclusion: The content mostly included theoretical and practical approaches at least once throughout the course. However, when considering content associated with patient safety-related sociocultural aspects, lower scores were found.
\end{abstract}

Keywords: Patient Safety; Education, Higher; Education, Nursing; Curriculum.

\section{Resumo}

Objetivo: Investigar conteúdos relacionados à segurança do paciente, contemplados nos currículos de cursos de graduação em Enfermagem de duas Instituições de Ensino Superior brasileiras. Método: Estudo descritivo, tipo survey, realizado com 119 alunos de cursos de Enfermagem (Licenciatura e Bacharelado), no período de agosto a setembro de 2016. Os tópicos investigados foram baseados no Patient safety curriculum guide: multi-professional edition. De posse dos dados, realizaram-se análises univariadas e bivariadas. Resultados: Dos 46 conteúdos investigados no questionário, dois tiveram escores elevados de não obtenção em atividades teóricas e/ou práticas, que são: "Cultura de culpa" e "Infecção comunitária". Alunos da Licenciatura e Bacharelado referiram maior aquisição em aulas teóricas $(p=0,012)$, enquanto os do Bacharelado atribuíram de forma equivalente teoria $e$ prática $(p=0,013)$. Conclusão: Os conteúdos estiveram contemplados, em sua maioria, na abordagem teórica e prática, ao menos uma vez no decorrer do curso. No entanto, quando se tratou de conteúdos ligados a aspectos socioculturais relacionados à segurança do paciente registraram-se escores menores.

Palavras-chave: Segurança do Paciente; Educação Superior; Educação em Enfermagem; Currículo.

\section{Resumen}

Objetivo: Investigar contenidos relacionados a seguridad del paciente, contemplados en programas de cursos de grado en Enfermería de dos Instituciones de Enseñanza Superior brasileñas. Método: Estudio descriptivo, tipo survey, realizado con 119 alumnos de cursos de Enfermería (Licenciatura y Bachillerato), de agosto a setiembre de 2016. Los tópicos investigados estaban basados en el Patient safety curriculum guide: multi-professional edition. Se realizaron análisis univariados y bivariados de los datos. Resultados: De 46 contenidos investigados, dos obtuvieron alto grado de desaprobación en actividades teóricas y/o prácticas: "Cultivo de culpa" e "Infección comunitaria". Los alumnos de Licenciatura y Bachillerato reportaron mayor adquisición en clases teóricas $(p=0,012)$, mientras los de Bachillerato reportaron equivalentemente a teoría y práctica $(p=0,013)$. Conclusión: Los contenidos estuvieron mayoritariamente contemplados en abordajes teóricos y prácticos al menos una vez durante e curso; aunque se registraron puntajes menores respecto de contenidos vinculados a aspectos socioculturales relacionados a seguridad del paciente.

Palabras clave: Seguridad del Paciente; Educación Superior; Educación en Enfermería; Currículum 


\section{INTRODUCTION}

Patient safety has been widely discussed worldwide and is recognized as an important quality indicator, especially due to the high incidence of adverse events associated with the provision of health care. ${ }^{1,2}$

Studies that estimated the occurrence of adverse events show a mortality rate ranging between 40 and 98 thousand patients/year in the United States., In Brazil, there is no accurate outlook about the magnitude of adverse events, although data point out that, every three minutes, more than two Brazilians die in a hospital (public or private), due to errors and other adverse events associated with professional care. ${ }^{5}$

Acknowledgement of the magnitude of this issue and the non-intentional harm caused by health care has triggered multiple reflections, especially on the training of healthcare professionals, which seems to be weak in terms of not following the fast rhythm of innovations in practice, changes in conditions, diversities, and workforce imposed in the last decades. ${ }^{6}$

Based on this, and in accordance with international regulatory agencies, the Brazilian Ministry of Health established the Patient Safety National Program in 2013, which has among its main goals to prevent and reduce the incidence of adverse events associated with healthcare services. In this document, the inclusion of the theme of patient safety in the curricula of healthcare courses was considered a priority, ${ }^{7}$ although information about the mechanisms used to evaluate this inclusion are not clear.

The evaluation of healthcare training has been difficult, especially due to the lack of systematic models of evaluation. Therefore, the World Health Organization (WHO) has proposed an evaluation based on research into topics present in the curricula of healthcare courses, to identify common themes in terms of frequency, as well as those less explored, which are available in the WHO patient safety curriculum guide: multiprofessional edition. ${ }^{8}$ This guide focuses on the training of students in healthcare courses and helps teachers to approach the theme in their classes.

Based on this, the objective of the present study was to investigate content associated with patient safety included in the curricula of undergraduate nursing courses of two Brazilian higher educational institutions.

\section{METHOD}

This was a cross-sectional survey study, carried out in the undergraduate nursing courses of two public higher educational institutions in Brazil, one in the state of São Paulo and the other in Brasilia, Federal District of Brazil. The choice of the institutions was purposeful and was based on the similarity of pedagogical political projects.

In these institutions, the nursing course is divided into two regimes: a bachelor's degree and bachelor's and licentiate degree. The first aims to train general nurses to perform in several healthcare areas, for promotion of health, prevention, and recovery from illnesses and harm. However, the bachelor's and licentiate degree course in nursing invests in the training of general nurses to perform with expertise in the health promotion area, in several nursing care practice areas, as well as becoming professors of professional training courses in nursing (training of nursing aides and technicians).

One hundred-nineteen nursing students who met the following inclusion criteria participated in the study: currently enrolled in one of the educational institutions, and attending the last period of the course. Students who were enrolled but were not attending classes were excluded.

Data collection occurred from August to September 2016, guided by a questionnaire that sought to identify in which contexts the content regarding patient safety had been acquired throughout the course, according to the WHO patient safety curriculum guide. ${ }^{8}$ The interviews were carried out collectively in the classrooms of the respective institutions.

The instrument used was previously validated by seven experts in the area, using the Likert scale ${ }^{9}$ for consensus. A criterion was established that the item should reach the minimum entry percentage of $75 \%$ in the scores "important" or "very important" for inclusion in the final questionnaire.

Initially, the manual organization of the questionnaires was carried out, followed by double-entry typing in Microsoft Excel 2010, which was imported to the Statistical Package for the Social Sciences 20 software (SPSS). Armed with the data, univariate and bivariate analyses were carried out. Because of the categorical variables, the chi-square was used, and the significance level was $p \leq 0.05$, with a $95 \%$ confidence interval.

The research project was approved by the institutions' research ethics committee. The development of the study complied with all ethical principles that guide research involving human beings.

\section{RESULTS}

Among the 119 participants, 79 (66.4\%) were enrolled in the bachelor degree course in nursing. As observed in Table 1, with regard to the sociodemographic variables, there was a prevalence of the feminine gender (86.6\%), with age group between 21 and 25 years (84.0\%). Most students had carried out scientific initiation $(67.2 \%)$ and did not have previous training or education in the healthcare area (87.4\%).

The main theoretical aspects that support the training of future healthcare professionals regarding safe care or patient safety are presented in Table 2 .

Considering the specificities of each item that allow its exploration in both theoretical and practical aspects, interesting and worrying results were observed. Of the 46 items, only two ("culture of blame" and "community-acquired infection") were not reported in either theoretical or practical activities, which indicates impairment in two important aspects of the topics "patient safety" and "prevention and control of infections." When cross-checking of data between the responses of students enrolled in the courses and the total score of tracking terms 
Table 1. Characteristics of the students regarding sociodemographic and training variables, Brazil, 2016.

\begin{tabular}{|c|c|c|}
\hline & $\mathbf{N}$ & $\%$ \\
\hline \multicolumn{3}{|l|}{ Gender } \\
\hline Male & 16 & 13.4 \\
\hline Female & 103 & 86.6 \\
\hline \multicolumn{3}{|l|}{ Age group } \\
\hline 18 to 25 & 106 & 89.1 \\
\hline 26 to 30 & 8 & 6.7 \\
\hline Older than 30 & 5 & 4.2 \\
\hline \multicolumn{3}{|l|}{ Regime of the course } \\
\hline Licentiate and Bachelor degree & 40 & 33.6 \\
\hline Bachelor degree & 79 & 66.4 \\
\hline \multicolumn{3}{|l|}{$\begin{array}{l}\text { Did the student carry out scientific } \\
\text { initiation? }\end{array}$} \\
\hline Yes & 80 & 67.2 \\
\hline No & 39 & 32.8 \\
\hline \multicolumn{3}{|c|}{$\begin{array}{l}\text { Did the student have previous skills } \\
\text { or training in the healthcare area? }\end{array}$} \\
\hline Nursing technician & 8 & 6.7 \\
\hline Nursing aide & 3 & 2.5 \\
\hline Other(s) & 2 & 1.6 \\
\hline No & 106 & 89.1 \\
\hline \multicolumn{3}{|c|}{$\begin{array}{l}\text { Does the student work or did work as } \\
\text { a professional in the healthcare area? }\end{array}$} \\
\hline Yes & 10 & 8.4 \\
\hline No & 109 & 91.6 \\
\hline
\end{tabular}

was carried out, it was observed that, for licentiate and bachelor degree students, most terms were perceived in theoretical classes $(p=0.012)$, whereas for bachelor degree students there was an association with the knowledge perceived in both theory and practice $(p=0.013)$, as shown in Table 3 .

\section{DISCUSSION}

The content associated with patient safety in the curricula of undergraduate courses in nursing of the educational institutions studied mostly included theoretical and practical approaches at least once throughout the course. However, when considering content associated with patient safety-related sociocultural aspects, such as teamwork and safety culture, lower achievement scores were found.

Healthcare institutions tend to overestimate content that promotes clinical skills, such as diagnosis and treatment of diseases, ${ }^{10}$ and actions focused on patient safety-related processes and interpersonal relationships in healthcare teams take a back seat.
Therefore, the scores attributed to a "culture of blame" were lower than expected, and interpreting the error as a failure may be a mistake. The fact that students reported that they did not have the necessary contact with the subject "culture of blame" contributes to the perpetuation of the punitive ideology regarding errors, not allowing students to understand errors as an opportunity to learn, as well as to develop abilities to prevent them. ${ }^{11}$

With regard to this subject, a study ${ }^{12}$ conducted in China showed that students in the healthcare area felt more comfortable with activities associated with clinical safety, such as hand hygiene, infection control, and safe medication administration practices, than with sociocultural aspects or those contextually dependent on patient safety, such as teamwork, safety risk management, and safety culture.

Currently, institutions work through a sociocultural perspective, recognizing that the interaction between knowledge and individual learning is dependent on cultural conditions under which learning takes place. Therefore, for implementation of sociocultural skills focused on patient safety in the healthcare education, the incorporation of content in classrooms, supported by actions and modeling of concepts in a wide and focal consistent form, applied to the students' reality, is required. ${ }^{13}$

Improving the integration and global implementation of patient safety concepts in classrooms and clinical practice is required, with integration between what is being taught and the healthcare reality. This may help in resolving inconsistencies in the way patient safety issues are dealt with by different preceptors. ${ }^{14}$

Two complementary variables showed very divergent behaviors. The tracking term "community-acquired infection" was pointed out by $42.0 \%$ of the students as not achieved, whereas "hospital infection" was indicated by only $2.5 \%$. This result is reflection of the hospital-centric training model of healthcare professionals, strongly focused on "patient cure" and far from the prevention principles of HAls. These still have a considerable impact on morbidity and mortality rates in the intra- and extrahospital environment, leading to the increase in length and cost of hospital stays, thus being recognized as a serious global public healthcare problem for several decades. ${ }^{15}$

The traditional "invisibility" given to community-acquired infection results from difficulties in conceptualizing the term, listing risk factors and prevention and control measures, as shown in studies conducted in Brazil ${ }^{15,16}$ and abroad. ${ }^{17}$

Strategies for prevention and control of infections must be expanded to all healthcare areas, and this primarily occurs through the training of professionals..$^{10,16}$ One of the major difficulties in the prevention of healthcare-associated infections refers to the education and training of human resources sensitive to the problem, aware of and responsible for the maintenance of a biologically safe environment, which is crucial to providing safe care. ${ }^{18}$

This requires that the theme of patient safety is transversally explored with greater depth throughout the course, in order to optimize learning opportunities, establishing a connection with the practice performed. 
Table 2. Distribution of items associated with patient safety reported by the undergraduate nursing students according to the source acquisition (theory or practice), Brazil, 2016.

\begin{tabular}{|c|c|c|c|c|c|}
\hline Topic & Tracking terms & $\begin{array}{l}\text { Theoretical } \\
\text { classes }\end{array}$ & $\begin{array}{l}\text { Practical } \\
\text { classes }\end{array}$ & $\begin{array}{l}\text { Theory and } \\
\text { practice }\end{array}$ & $\begin{array}{c}\text { Not } \\
\text { achieved }\end{array}$ \\
\hline & & $\%$ & $\%$ & $\%$ & \\
\hline \multirow{5}{*}{ What is patient safety? } & Notions of patient safety & 37.0 & 0.8 & 61.3 & 0.8 \\
\hline & Care with focus on patients & 30.3 & 4.2 & 64.7 & 0.8 \\
\hline & Adverse events & 70.6 & 0.8 & 24.4 & 4.2 \\
\hline & $\begin{array}{l}\text { Errors involving human, environmental, } \\
\text { or organizational factors }\end{array}$ & 63.9 & 0.8 & 30.8 & 5.0 \\
\hline & Culture of blame & 26.1 & 7.6 & 4.2 & 62.2 \\
\hline \multirow{7}{*}{$\begin{array}{l}\text { Reasons why the application of } \\
\text { human factors is important for } \\
\text { patient safety }\end{array}$} & $\begin{array}{l}\text { Use of ergonomic principles in patient } \\
\text { care }\end{array}$ & 28.6 & 4.2 & 49.6 & 17.6 \\
\hline & $\begin{array}{l}\text { Fatigue and stress during professional } \\
\text { performance }\end{array}$ & 50.4 & 14.3 & 23.5 & 11.8 \\
\hline & Safety in the use of equipment & 20.2 & 3.4 & 75.6 & 0.8 \\
\hline & N95 or PFF2 & 42.9 & 2.5 & 31.9 & 22.7 \\
\hline & Regulatory Standard no. 32 (NR32) & 25.2 & 0.8 & 68.1 & 5.9 \\
\hline & $\begin{array}{l}\text { Standard precautions/Use of personal } \\
\text { protective equipment }\end{array}$ & 10.9 & 0 & 89.1 & 0 \\
\hline & Workers' immunization & 40.3 & 0 & 55.5 & 4.2 \\
\hline \multirow{6}{*}{ Effective team } & Work's organizational structure & 51.3 & 1.7 & 42.0 & 5.0 \\
\hline & Interdisciplinarity/Healthcare team & 35.3 & 3.4 & 59.7 & 1.7 \\
\hline & Effective leadership & 48.7 & 2.5 & 44.5 & 4.2 \\
\hline & Resolution of conflicts & 42.9 & 5.9 & 36.1 & 15.1 \\
\hline & Supervision & 45.4 & 3.4 & 44.5 & 6.7 \\
\hline & $\begin{array}{l}\text { Communication process in the work } \\
\text { environment }\end{array}$ & 31.9 & 1.7 & 61.3 & 5.0 \\
\hline \multirow{3}{*}{$\begin{array}{l}\text { Learning through errors to } \\
\text { prevent damage }\end{array}$} & Errors/Types of errors & 37.0 & 1.7 & 61.3 & 0 \\
\hline & How to learn with errors & 37.0 & 12.6 & 31.9 & 18.5 \\
\hline & Notification of errors & 50.4 & 11.8 & 24.4 & 13.4 \\
\hline \multirow{2}{*}{$\begin{array}{l}\text { Use of quality improvement } \\
\text { methods for improvement in } \\
\text { care }\end{array}$} & Indicators of quality of care & 45.4 & 2.5 & 45.4 & 6.7 \\
\hline & Improvement in care & 31.9 & 0 & 63.9 & 4.2 \\
\hline \multirow{3}{*}{ Medication safety } & Side effects & 69.7 & 0.8 & 24.4 & 5.0 \\
\hline & $\begin{array}{l}\text { Medication system and processes } \\
\text { of prescription, distribution, and } \\
\text { administration of medications }\end{array}$ & 16.8 & 3.4 & 76.5 & 3.4 \\
\hline & Medication errors & 47.9 & 0.8 & 48.7 & 2.5 \\
\hline
\end{tabular}


Continued Table 2.

\begin{tabular}{|c|c|c|c|c|c|}
\hline Topic & Tracking terms & $\begin{array}{c}\text { Theoretical } \\
\text { classes } \\
\%\end{array}$ & $\begin{array}{c}\text { Practical } \\
\text { classes } \\
\%\end{array}$ & $\begin{array}{c}\text { Theory and } \\
\text { practice } \\
\%\end{array}$ & $\begin{array}{c}\text { Not } \\
\text { achieved } \\
\%\end{array}$ \\
\hline \multirow{3}{*}{$\begin{array}{l}\text { Interaction with patients and } \\
\text { caregivers }\end{array}$} & $\begin{array}{l}\text { Legislations and rights of healthcare } \\
\text { system users }\end{array}$ & 73.1 & 0.8 & 19.3 & 6.7 \\
\hline & $\begin{array}{l}\text { Respect for patients' healthcare needs } \\
\text { (cultural aspects and beliefs) }\end{array}$ & 28.6 & 0 & 71.4 & 0 \\
\hline & $\begin{array}{l}\text { Family's responsibility and integration } \\
\text { in patient care }\end{array}$ & 26.9 & 2.5 & 68.9 & 1.7 \\
\hline \multirow{17}{*}{$\begin{array}{l}\text { Prevention and control of } \\
\text { infections }\end{array}$} & HAls & 63.9 & 1.7 & 26.9 & 7.6 \\
\hline & Hospital infection & 53.8 & 1.7 & 42.0 & 2.5 \\
\hline & Community acquired infection & 48.7 & 0 & 9.2 & 42.0 \\
\hline & Biofilm & 71.4 & 1.7 & 16.0 & 10.9 \\
\hline & Pandemic & 72.3 & 5.9 & 21.8 & 0 \\
\hline & Epidemic & 73.9 & 0.8 & 19.3 & 5.9 \\
\hline & Outbreak & 56.3 & 0.8 & 21.8 & 21.0 \\
\hline & Infection risks & 37.0 & 0 & 62.2 & 0.8 \\
\hline & Infection chain and cross-infection & 62.2 & 1.7 & 30.3 & 5.9 \\
\hline & Hand hygiene & 10.1 & 1.7 & 87.4 & 0.8 \\
\hline & Disinfection & 25.2 & 0 & 73.9 & 0.8 \\
\hline & Antisepsis & 7.6 & 0.8 & 90.8 & 0.8 \\
\hline & Antisepsis techniques & 16.8 & 1.7 & 80.7 & 0.8 \\
\hline & $\begin{array}{l}\text { Precautionary and control measures of } \\
\text { infections }\end{array}$ & 22.7 & 0 & 75.6 & 1.7 \\
\hline & Isolation & 25.2 & 1.7 & 70.6 & 2.5 \\
\hline & Microbial resistance & 60.5 & 0.8 & 32.8 & 5.9 \\
\hline & Processing of contaminated articles & 47.1 & 38.6 & 14.3 & 0 \\
\hline
\end{tabular}

Note: HAls - Healthcare-associated infections.

Table 3. Association between the regime of the course (Bachelor or Licentiate degree) and the number of tracking terms reported.

\begin{tabular}{llllcc}
\hline Outcome & Regime of the course & N & Mean & $\begin{array}{c}\text { Standard } \\
\text { deviation }\end{array}$ & $\begin{array}{c}p \\
\text { value }\end{array}$ \\
\hline Number of tracking terms reported (theoretical classes) & Licentiate and Bachelor degree & 40 & 16.10 & 7.64 & 0.012 \\
& Bachelor degree & 79 & 20.45 & 9.32 & \\
\multirow{2}{*}{ Number of tracking terms reported (practical classes) } & Licentiate and Bachelor degree & 40 & 1.12 & 2.62 & 0.930 \\
& Bachelor degree & 79 & 1.08 & 1.82 & \\
Number of tracking terms reported (theory and practice) & Licentiate and Bachelor degree & 40 & 25.17 & 9.35 & 0.013 \\
\cline { 2 - 5 } & Bachelor degree & 79 & 20.51 & 9.54 & \\
\hline
\end{tabular}


The present study presents limitations, especially due to the design used (cross-sectional), which does not allow for follow-up of the participants throughout their education. Therefore, the interaction with an observational phase would make it possible to evaluate the theoretical-practical conciliation in the working field, thus identifying failures and errors in due time.

\section{CONCLUSION}

The content was mostly included in the theoretical and practical approach at least once throughout the course. However, when considering content associated with patient safety-related sociocultural aspects, lower scores were found, proving that the education on patient safety is still focused on a curative and private approach, especially based on the development of clinical skills.

In addition, content associated with prevention and control of community-acquired infections also showed low achievement scores, due to the greater emphasis given to the hospital-centric training model of healthcare professionals.

\section{REFERENCES}

1. Singh $\mathrm{H}$, Sittig DF. Measuring and improving patient safety through health information technology: The Health IT Safety Framework. BMJ Qual Saf [Internet]. 2016 April; [cited 2017 May 5]; 25(4):22632. Available from: https://www.ncbi.nlm.nih.gov/pmc/articles/ PMC4819641/

2. Duarte SCM, Stipp MAC, Silva MM, Oliveira FT. Adverse events and safety in nursing care. Rev Bras Enferm [Internet]. 2015 Jan; [cited 2017 May 5]; 68(1):144-54. Available from: http://www.scielo.br/scielo. php?script=sci_arttext\&pid=S0034-71672015000100144\&lng=en\&nr $\mathrm{m}=$ iso

3. Kohn LT, Corrigan JM, Donaldson MS, eds. To err is human: building a safer health system. Washington (DC): National Academy Press; [Internet]. 2000. Available from: https://www.ncbi.nlm.nih.gov/books/ NBK225182/pdf/Bookshelf_NBK225182.pdf

4. James JT. A new, evidence-based estimate of patient harms associated with hospital care. J Patient Saf [Internet]. 2013 Sep; [cited 2017 May 5]; 9(3):122-8. Available from: https://www.ncbi.nlm.nih.gov/ pubmed/23860193

5. Couto RC, Pedrosa TMG, Rosa MB. Instituto de Estudos de Saúde Suplementar - IESS. Erros acontecem: A força da transparência no enfrentamento dos eventos adversos assistenciais em pacientes hospitalizados. Belo Horizonte;2016. Available from: http://documents. scribd.com.s3.amazonaws.com/docs/5x5i1j985c5jwcsp.pdf

6. Rosse Fv, Bruijne M, Suurmond J, Essink-Bot ML, Wagner C. Language barriers and patient safety risks in hospital care: A mixed methods study. Int J Nurs Stud [Internet]. 2016 Feb; [cited 2017 May 5]; 54:4553. Available from: http://www.sciencedirect.com/science/article/pii/ S0020748915000747
7. Ministério da Saúde (BR). Portaria №529, de 1ํ de Abril de 2013: Institui o Programa Nacional de Segurança do Paciente (PNSP). Brasília (DF): Ministério da Saúde; 2013. [Internet]. 2013 Apr; [cited 2017 Jul 18] Available from: http://www.saude.mt.gov.br/upload/controle-infeccoes/ pasta2/portaria-msgm-n-529-de-01-04-2013.pdf

8. World Health Organization - WHO. Patient safety curriculum guide: multiprofessional edition [Internet]. Geneva: World Health Organization;2011 [cited 2013 Jul 31]. Available from: http://www.who.int/patientsafety/ education/curriculum/en/

9. Li Q. A novel Likert scale based on fuzzy sets theory. Expert Syst Appl [Internet]. 2013 April; [cited 2017 May 5]; 40(5):1609-18. Available from: http://www.sciencedirect.com/science/article/pii/S095741741201069X

10. Bohomol E, Cunha ICKO. Teaching patient safety in the medica undergraduate program at the Universidade Federal de São Paulo. Einstein (São Paulo) [Internet]. 2015 Jan; [cited 2017 May 5]; 13(1):713. Available from: http://www.scielo.br/scielo.php?script=sci_ arttext\&pid=S1679-45082015000100003\&lng=en\&nrm=iso

11. Paese F, Sasso GTMD. Patient safety culture in primary health care. Texto Contexto Enferm [Internet].2013 Abr/Jun; [cited 2017 May 5];22(2):30210. Available from: http://www.scielo.br/pdf/tce/v22n2/v22n2a05

12. Doyle P, VanDenKerkhof EG, Edge DS, Ginsburg L, Goldstein DH Self-reported patient safety competence among Canadian medical students and postgraduate trainees: a cross-sectional survey. BMJ Qual Saf [Internet]. 2015 Feb; [cited 2017 May 5]; 24(2):135-41. Available from: https://www.ncbi.nlm.nih.gov/pmc/articles/PMC4316835/

13. Tregunno D, Ginsburg L, Clarke B, Norton P. Integrating patient safety into health professionals' curricula: a qualitative study of medical, nursing and pharmacy faculty perspectives. BMJ Qual Saf [Internet] 2014 Aug; [cited 2017 May 5]; 23(3):257-64. Available from: http:// qualitysafety.bmj.com/content/23/3/257

14. Wong BM, Etchells EE, Kuper A, Levinson W, Shojania KG. Teaching quality improvement and patient safety to trainees: a systematic review. Acad Med [Internet]. 2010 Aug; [cited 2017 May 5]; 85(9):142539. Available from: http://journals.Iww.com/academicmedicine/ Fulltext/2010/09000/Teaching_Quality_Improvement_and_Patient Safety_to.13.aspx

15. Sousa AFL, Queiroz AAFLN, Oliveira LB, Valle ARMC, Moura MEB. Social representations of community-acquired infection by primary care professionals. Acta Paul Enferm [Internet].2015 Aug; [cited 2017 May 5] 28(5):454-9. Available from: http://www.scielo.br/scielo.php?script=sci_ arttext\&pid=S0103-21002015000500454\&lng=en\&nrm=iso\&tlng=en

16. Valle ARMC, Andrade D, Sousa AFL, Carvalho PRM. Infection prevention and control in households: nursing challenges and implications. Acta Paul Enferm [Internet]. 2016 Apr; [cited 2017 May 5]; 29(2):239-44. Available from: http://www.scielo.br/scielo. php?script=sci_arttext\&pid=S0103-21002016000200239\&lng=en\&n $\mathrm{rm}=$ iso\&tlng=en

17. Shang J, Ma C, Poghosyan L, Dowding D, Stone P. The prevalence of infections and patient risk factors in home health care: a systematic review. Am J Infect Control [Internet]. 2014; [cited 2017 May 5]; 42(5):479-84. Available from: https://www.ncbi.nlm.nih.gov/pmc/ articles/PMC4438760/

18. Brusaferro S, Arnoldo L, Cattani G, Fabbro E, Cookson B, Gallagher $G$, et al. Harmonizing and supporting infection control training in Europe. J Hosp Infect [Internet]. 2015; [cited 2017 May 5]; 89(4):3516. Available from: http://www.sciencedirect.com/science/article/pii/ S0195670115000031

a Originated from the thesis entitled: "Segurança do paciente no ensino de graduação: subsídios para repensar as disciplinas na perspectiva do guia curricular multiprofissional da Organização Mundial da Saúde" (Patient safety in undergraduate education: subsidies to rethink disciplines in the perspective of the multi-professional curriculum guide of the World Health Organization), presented to the Ribeirão Preto College of Nursing at the University of São Paulo in 2016. 